\title{
ETHNO-MEDICINAL USES OF PLANTS IN PUTALI BAZAR MUNICIPALITY OF SYANGJA DISTRICT, NEPAL
}

\author{
Puspa Aryal ${ }^{1}$ and Chandra Bahadur Thapa ${ }^{1^{*}}$ \\ 1Department of Botany, Prithvi Narayan Campus, Tribhuvan University, Pokhara, Nepal \\ *For correspondence: cbthapadr@yahoo.com
}

\begin{abstract}
In the several rural areas of Nepal, due to lack of modern health facilities, people still rely on traditional medicine practice. This present research seeks to explore the information of medicinal plants used by the people of Putalibazar municipality of Syangja district. In total of 108 plants species belonging to 100 genera and 60 families were recorded as ethno medicinal plants of Putalibazar Municipality. In which dominant families were Poaceae, Fabaceae, Moraceae, Asteraceae, Lamiaceae, and Euphorbiaceae respectively with 7, 6, 5, 5 and 4 genera. On the basis of their habit, the plants species were climbers 7 spp. $(6.48 \%)$, herbs 48 spp. (44.44\%), shrubs 24 spp. (21. 82\%) and trees 29 spp. (26. 85\%). Some of the useful species are under the serious threat due to unsustainable activities. Hence, a proper documentation of useful plants with their present status and local traditional knowledge as well as practices is urgently needed. Effort should also be initiated to implement appropriate conservation measures for preservation and sustainable uses of these useful plants.
\end{abstract}

Key words: Conservation, disease, ethno-medicine, traditional medicine.

\section{INTRODUCTION}

Nepal is the natural botanical garden of floristic biodiversity in the world, because of its geographical, ecological, altitudinal and climatic variations. Despite being small country on the basis of land area, Nepal is fully rich on the basis of bio-diversity with no doubt. The country is the shelter to a large number of medicinal plants which are used as major source of treatment for different kinds of diseases, mainly in rural areas where allopathic treatment is lacking. It has been estimated that approximately $80 \%$ of the developing world rely on traditional medicine and $85 \%$ of the traditional medicines contain plants and their extract (Sheldon et al., 1997).

In Nepal about $70-80 \%$ of population in mountain region depends on the traditional medicines for health care (Manandhar, 1980) and in spite of wide spread use of allopathic medicine, more than $80 \%$ of the rural Nepalese people rely on traditional remedies that involve the use of local plants in various forms and combinations (Rajbhandari and Bajracharya, 1994).

Nepal is a multiethnic and multilingual country and has about 130 different ethnic groups speaking about 120 languages (CBS, 2013). In Nepal, about $80 \%$ of the people, mainly of the rural communities, depend on herbal plants as medicine for their primary health care (Ghimire et al., 2000).

Recently updated database revealed a total of 1950 species of medicinal plants used in Nepal and out of which 1906 species are identified under vascular group, comprising 1614 native, 192 introduced or cultivated and 100 naturalized taxa (Ghimire, 2008). According to Bhattarai and Ghimire (2006), 49\% of traditional 
medicinal plants are herbs, 29\% trees, 14\% shrubs and 9\% climbers. In Nepal, it is reported that traditional healers use 1792 plant species as medicine (Baral and Kurmi, 2006). During the last few decades, there has been an increasing interest in the study of the medicinal plants and their traditional use in different part of the world (Lev, 2006). Documenting the indigenous knowledge through ethno-botanical studies is important for the conservation and utilization of biological resources, and also for future references (Sen, 1993).

In Nepal, because of the rural nature of the country, modern health services and other organized systems of traditional medicine are not available to the bulk of the population. Indigenous knowledge about the use of plants as medicine remains the foundation of primary healthcare in most of the remote parts of Nepal. The majority of Nepal's population rely on traditional herbal therapy as it is cheap, convenient and readily available (Manandhar, 2002). Traditional botanical knowledge of the indigenous communities relating to uses and management of wild plant resources is extensive (Cotton, 1997).

\section{MATERIALS AND METHODS}

\section{Study area}

The study was conducted in Putalibazar Municipality, Syangja. Putalibazar is the biggest municipality in Syangja district. It was established on 2054 B.S. by merging the five village development committees i.e. Putlikhet, Karendada, Chandikalika, Satupasal and Ganeshpur. It covers an area $146.21 \mathrm{~km}^{2}$. It consists mainly the hills and small plateau. The area has a temperate monsoon climate with four different seasons; winter, spring, summer and monsoon.

The present study was conducted over a period of a year between 2016 and 2017.
Method of selecting information depends on the distribution of local people having folk knowledge. Generally, elderly people were given top priority. They were requested to collect specimen of the plants species on site. Those informants were traditional healers themselves or had tradition of healing in their families and had knowledge of the medicinal use of plants. The wealth of medicinal plant knowledge among the people of this area is based on beliefs and observations. The ethno medicinal data were collected through interviews with traditional healers, and observation of plant specimens.

\section{Results and Discussion}

During the field survey, ethno-medicinal information of 60 plant families belonging to 100 genera and 108 species were identified. Plant species which are used in traditional medicine are enumerated with their botanical name followed by local name, family and the use of plants parts in the treatment of various diseases. In the present investigation, all the medicinal plants were identified and their number of families (60), genus (98) and species (110) were identified. (Table 1)

Altogether 108 species of medicinal plants, which were identified on the basis of their habit. Among them $44.44 \%$ were herbs, $22.23 \%$ shrubs, $26.85 \%$ trees and $6.48 \%$ climbers. Different parts of the medicinal plant used by the people of this area are bark, bud, flower, fruit, latex/ gum, leaves, rhizome, root, seed and whole plant.

Among these parts used for the preparation of medicine, roots of 26 species of plant were found to be most frequently used followed by all part of the plant. i.e. leaves (23 species), buds (19 species), whole plant (13 species), fruit (13 species), seed (10 species), bark (9 species), rhizome (8 species), flower (8 species), latex (6 species) and stem (5 species) of plants.

In the present ethno-medico-botanical survey, 
a total of 108 species under 98 genera of 60 families which are used for the treatment of different diseases were documented. Similar findings were reported by Manandhar (1980). The recorded ethno-medicinal plants were used in treatment of various diseases such as cuts and wounds, skin diseases, fever, catarrh, boils, burns, scabies, dogs and insect bites, ringworm, ulcers, allergy, pimples, leukoderma, cholera, diarrhea, dysentery, headache, gastritis etc. Majority of the plants species described in the present investigation frequently used by the people of this area are Tinospora cordifolia, Centella asiatica, Eclipta prostate, Mimosa pudica, Ocimum sanctum, Bahunia purpurea, Magnifera indica, Azadiracta indica, Aloe vera, Acorus calamus and Zingiber officinale. Similar findings were reported by

In the present investigation, the dominated families of the medicinal plants on the basis of their uses are Poaceae (7 spp.), followed by Fabaceae (6 spp.), Moraceae (5 spp.) and
Compositae, Euphorbiaceae and Lamiaceae 4 species each. The frequently used plants part for medicinal values, used in present study is root (26 spp.), followed by leaves (23 species), buds (19 species), whole part (13 species), fruit (13 species), seed (10 species), bark (9 species), rhizome (8 species), flower (8 species), latex (6 species) and stem (5 species) of plants. Among the recorded species, herbs $(44.55 \%)$ were found to be dominating over trees $(27.27 \%)$, shrubs $(21.82 \%)$ and $6.36 \%$ climbers The present study emphasized that there is a profound and growing knowledge gap between old and younger generation. People of more than 50 years' age know a lot about wild plant product as compared to younger generation. Our society is changing gradually and their economic status also changing. Government has established some healthcare centre in the rural area. This may gradually change the existing pattern of indigenous knowledge system of healthcare

\section{Table 1: Enumerated list of medicinal plants}

\begin{tabular}{|l|l|l|l|}
\hline Botanical Name & Common name & Family & Parts used \\
\hline Abelmoschus esculantus (Linnaceus) Moench & Vindi & Malvaceae & Whole plant \\
\hline Abies spectabilis (D.Don) Mirbel & Salla & Pinaceae & Leaves \\
\hline Achyranthus aspera L. & Datiwan & Amaranthaceae & Root, stem \\
\hline Acorus calamus Linn. & Bojho & Araceae & Rhizome \\
\hline Adhatoda vasica Nees. & Asuro & Acanthaceae & Root, bud \\
\hline Aegle marmelos (L.) Corr & Bel & Rutaceae & Fruit \\
\hline Agave cantala (Roxburgh.ex.Salmdyck) & Ketuki & Agavaceae & Root, leaves \\
\hline Ageratum houstanianum Miller. & Nilo gandhe & Compositae & Leaves \\
\hline Allium cepa L. & Pyazz & Amaryllidaceae & Rhizome \\
\hline Aloe vera (L.) Burm.F. & Gheukumari & Asphodelaceae & Whole plant \\
\hline Amaranthus viridis L. & Seto lunde & Amaranthaceae & Leaves \\
\hline Amomum aromaticum Roxb. & Alainchi & Typhaceae & Seed \\
\hline Ananas comosus (L.) Merr. & Darae & Bromilaceae & Fruit, leaves \\
\hline Artemisia capillaris thumb. & Tite pati & Compositae & Leaves \\
\hline Artocarpus heterophyllus Lamark. & Rukh katahar & Moraceae & Root, latex, seed \\
\hline
\end{tabular}




\begin{tabular}{|c|c|c|c|}
\hline Artocarpus lakoocha Wallich. Ex.Roxburghii & Badahar & Moraceae & Bark \\
\hline Asparagus racemosus Willd. & Kurilo & Asparagaceae & Root \\
\hline $\begin{array}{l}\text { Aspidium caryotideum Wall.ex. Hook } \\
\text {.andGrev }\end{array}$ & Kali neuro & Dryopteridaceae & Leaves \\
\hline Azadiracta indica A. Juss. & Neem & Meliaceae & Leaves \\
\hline Bahunia purpurea L. & Taki & Fabaceae & Root, flower \\
\hline Berberis aristata DC. & Chutro & Berberidaceae & Root, bark \\
\hline Butea monosperma Lam. Taub & Palash & Fabaceae & Latex, flower \\
\hline Cajanas cajan (L.) mill.sp & Arhar & Fabaceae & Bud \\
\hline Callicarpa macrophylla vahl. & Daedalo & Verbenaceae & Root, fruit \\
\hline Calotropis gigantia (L.) W.T.Aiton & Aank & Asclepiadaceae & Latex, leaves \\
\hline Cannabis sativa $\mathrm{L}$. & Ganja & Cannabaceae & Leaves \\
\hline Capsicum annum L. & Akabare khursani & Solanaceae & Fruit \\
\hline Carica papaya L. & Mewa & Caricaceae & Latex \\
\hline Cassia tora $\mathrm{L}$. & Tapre & Fabaceae & Seed \\
\hline Castonopsis indica Roxb. Ex. Lindl. & Kadus & Fagaceae & Bud \\
\hline Catharanthus roseus (L.) G Don,1837 & Sadabahar & Apocynaceae & Bud \\
\hline Celosia argentea L. & Sahasra jari & Amaranthaceae & Root \\
\hline Centella asiatica (L.) & Ghodtapre & Umbelliferae & Whole plant \\
\hline Chenopodium album L. & Bethe & Chenopodiaceae & Flower, leaves \\
\hline $\begin{array}{l}\text { Choerospondias axillaris (Roxb.) B.L. Burtt. } \\
\text { and A.W. Hill. }\end{array}$ & Lapsi & Anacardiaceae & Fruit \\
\hline Cinnamomum tamala Nees and Eberm. & Tejpaat & Lauraceae & Leaves, bark \\
\hline Circium arvense (L.) Scop. & Thakailo & Asteraceae & Bud \\
\hline Cissampelos pareira $\mathrm{L}$. & Gudargano & Menispermaceae & Rhizome \\
\hline Citrus aurantifolia (Christm.) Swingle & Kagati & Rutaceae & Fruit \\
\hline $\begin{array}{l}\text { Cleistocalyx operculatus (Roxburgh). Murrey } \\
\text { and Perry. }\end{array}$ & Kyamuno & Myrtaceae & Bark, leaves \\
\hline Coffea arabica L. & Kafi & Rubiaceae & Seed \\
\hline Colocasia escuanta (L.) Schott & Gaabha & Araceae & Root \\
\hline Colocasia fallax Schott & Jaluko & Araceae & Bud \\
\hline Crateva religiosa Forst. F & Siplikan & Capperaceae & Bud \\
\hline Curculigo orchiodes Geertn. & Kalo musli & Hypoxidaceae & Root \\
\hline Curcuma caesia Roxb & Kalo haledo & Zinziberaceae & Rhizome \\
\hline Cuscuta europaea L. & Aakashbeli lahara & Convolvulaceae & Whole plant \\
\hline Cynodon dactylon (L.) Pers. & Dubo & Poaceae & Whole plant \\
\hline
\end{tabular}




\begin{tabular}{|c|c|c|c|}
\hline Dendrocalamus hemiltonii Gamble & Baans & Poaceae & Young stem \\
\hline Desmostachya bipinnata (L.) Stapf. & Kush & Poaceae & Root \\
\hline Drymaria cordata L. Willd. ex.. R and S & Avijalo & Caryophyllaceae & Whole plant \\
\hline Drynaria propinqua (wall.exmett) J. Smith & $\begin{array}{l}\mathrm{B} \text { a } \mathrm{n} \quad \mathrm{g} \text { a } \mathrm{d} \text { i } \\
(\text { kammari) }\end{array}$ & Polypodiaceae & Rhizome \\
\hline Eclipta prostata (L.) L. & Bhringe jhar & Compositae & Whole plant \\
\hline Elaeocarpus ganitrus Roxb.ex.G.Don & Rudrakxya & Tiliaceae & Seed \\
\hline Euphorbia pulcherrima Willd. Ex.klotzsch & Lalupate & Euphorbiaceae & Latex, leaves \\
\hline Euphorbia royleana Boiss. & Siudi & Euphorbiaceae & Latex \\
\hline Ficus racemosa $\mathrm{L}$. & Dumri & Moraceae & Bark \\
\hline Ficus religiosa $\mathrm{L}$. & Pipal & Moraceae & Bud \\
\hline Fritillaria cirrhosa D.Don & Ban lasun & Liliaceae & Rhizome \\
\hline Glycin max (L.) Merr & Bhatmas & Fabaceae & Seed \\
\hline Gossypium arboretum L. & Kapaas & Malvaceae & Seed, root \\
\hline Hibiscus rosa-sinensis L. & Ghantiphool & Malvaceae & Leaves, flowers \\
\hline Impereta cylindrica $\mathrm{L}$. & Siru & Poaceae & Root \\
\hline Jatropha curcus L. & Sajiwan & Euphorbiaceae & Root, stem \\
\hline Juniperous indica. Bertol & Dhupi & Cupressaceae & Wood, seed \\
\hline Leersia hexandra Sw. & Karante jhar & Poaceae & Whole plant \\
\hline Lyonia ovalifolia (Wall.) Drude & Angeri & Ericaceae & Bud \\
\hline Magnifera indica L. & Aanp & Anacardiaceae & Bark \\
\hline Mentha longifolia L. Huds. & Vicks & Lamiaceae & Leaves, bud \\
\hline Mentha piperita L. & Pudina & Lamiacea & Whole plant \\
\hline Mimosa pudica L. & Lajjawati & Fabaceae & Bud \\
\hline Mirabilis jalapa L. & Malati phool & Nyctaginaceae & Root \\
\hline Morus australis Poir. & Kew kaphal & Moraceae & Leaves, root \\
\hline Muklia scabrella (L.f) Arn. & Golkakri & Cucurbitaceae & Root, leaves \\
\hline Musa paradisica $\mathrm{L}$. & Kera & Musaceae & $\begin{array}{l}\text { Root, stem, } \\
\text { leaves }\end{array}$ \\
\hline Mussaendra roxburghii $\mathrm{L}$. & Dhobini & Rubiaceae & Bud, root \\
\hline Nephrolepsis cordifolia (L.) K. Persl. & Pani amala & Nephrolepidaceae & Root \\
\hline Nyctanthes arbor-tristis L. & Parijat & Oleaceae & Leaves \\
\hline Ocimum sanctum L. & Tulsi & Lamiaceae & Leaves \\
\hline Oroxylem indicum (L.) Benth. Ex Kurz & Tatelo & Bignoniaceae & Seed, root \\
\hline Oxalis corniculata L. & Chariamilo & Oxalidiaceae & Whole plant \\
\hline Phyallanthus emblica L. & Amala & Euphorbiaceae & Fruit \\
\hline
\end{tabular}




\begin{tabular}{|c|c|c|c|}
\hline Piper longum Linn. & Pipla & Piperaceae & Fruits \\
\hline Pityrogramma calomelanas (L.) link. & $\begin{array}{l}\text { Kali sinki } \\
\text { (dankerno) }\end{array}$ & Pteridaceae & Leaves \\
\hline Pogostemon amarantoides Benth. & Rudilo & Lamiacea & Bud \\
\hline Prunus persica (L.) Batsch & Aaru & Rosaceae & Bark, fruit \\
\hline Psidium guajava L. & Belauti & Myrtaceae & Bud \\
\hline Rhaphidophora glauca (wall.) Schott. & Haddijor & Araceae & Whole plant \\
\hline Rhododendron arboretum smith. & Laligurans & Ericaceae & Bud, flower, bark \\
\hline Rhus insignis Hook. F & Bhalayo & Anacardiaceae & Fruit \\
\hline Rosa alba L. & Gulaaf & Rosaceae & Flower \\
\hline Rubus ellipticus sm. & Aenselu & Rosaceae & Bud \\
\hline Saccharum arundianacum Retz. & Ukhu & Poaceae & Roots \\
\hline Schefflers venulosa Harms & Kursimlo & Araliaceae & Bark \\
\hline Solanum nigrum L. & Kaligedi & Solanaceae & Fruit \\
\hline Solanum xanthocarpum L. & Kanthakari & Solanaceae & Whole plant \\
\hline Stephania elegans .Hook.F andThoms & Batulpate & Menispermiaceae & Rhizome \\
\hline Tegetes erecta L. & Sayapatri & Compositae & Flower, leaves \\
\hline Terminalia belerica Roxb. & Barro & Combretaceae & Fruit,bark \\
\hline Terminalia chebula Retz. & Harro & Combretaceae & Fruit \\
\hline $\begin{array}{l}\text { Thysanolaena latifolia (Roxb.ex.Hornem.) } \\
\text { Honda }\end{array}$ & Amriso & Poaceae & Root \\
\hline Tinospora cordifolia (Thunb.) Miers & Gurjo & Menispermaceae & Whole plant \\
\hline Urtica diocia $\mathrm{L}$. & Sisnu & Urticaceae & Bud \\
\hline Vitex negundo L. & Simali & Verbenaceae & Leaves \\
\hline Woodfordia fructicos (L.) Kurz. & Dhaero & Lythraceae & Bud, flower \\
\hline Zanthoxylum armatum DC. & Timur & Rutaceae & Seed \\
\hline Zingiber officinale Rose. & Adhuwa & Zinziberaceae & Rhizome \\
\hline Zizypus jujube Mill. & Bayer & Rhamnaceae & Root \\
\hline
\end{tabular}

\section{Conclusions}

Most of the inhabitants of Putali Bazar Municipality areas still practice traditional knowledge of medicinal plants. This reveals that the local people possesses good knowledge of herbal medicine but as people are going on modernization their knowledge of traditional uses of the plants may be lost in due course. So, it is important to study and keep records of the uses of plants by different tribes for studies on scientific basis and this traditional knowledge have to pass from generation to generation for the future preservation.

\section{ACKNOWLEDGEMENTS}

The authors are thankful to the people of Putalibazar Municipality who shared their 
valuable information. We would also like to thank to all who directly or indirectly helped us in the present study.

\section{REFERENCES}

Baral, S.R. and P.P Kurmi (2006). A compendium of medicinal plants in Nepal. Publisher Mrs. Rachana Sharma, 281, Maujubahal Chabahil, Kathmandu, Nepal.

Bhattarai, K.P and M.D Ghimire (2006). Commercially important medicinal and aromatic plants of Nepal and their distribution pattern and conservation measure along the elevation gradient of the Himalayas. Banko Janakario. 16: 3-13

CBS (2013) Statistical year book Nepal, GON, NPCS, Central Bureau of Statistic Kathmandu, Nepal.

Cotton, C.M., (1997). Ethnobotany. Principles and applications. John Wiley and Sons, U.K.

Ghimire, S.K. (2008). Sustainable harvesting and management of medicinal plants in Nepal Himalaya; current issues knowledge gaps and research priorities. In medicinal plants of Nepal. An anthology of contemporary research (P.K. Jha, S.B. Karmacharya, M.K Chettri, C.B. Thapa and B.B. Shrestha. eds.) PP 2544, Ecological Society of Nepal.
Ghimire, S.K., A.K Shrestha, K.K Shrestha, and P.K Jha. (2000). Plant resource use and human impact around Royal Bardiya National Park, Nepal. J. Nat.His.Mus.19:326.

Lev, E. (2006). Ethno-diversity within current ethno-pharmacology as part of Israeli traditional medicine. A review journal of ethno-biology and ethno-medicine.2:4

Manandhar N.P. (2002). Plants and people of Nepal. Timber press Portland Oregon USA.

Manandhar, N.P. (1980). Medicinal plants of Nepal Himalayans Ratna Pustak Bhandar, Kathmandu, Nepal.

Rajbhandari, T.K and J.M Bajracharya (1994). National status paper on NTFPs, medicinal and aromatic plant. In: processing of national seminar of forest and soil conservation and herb production and processing co. Ltd. Kathmandu Nepal.

Sen, P, (1993). Therapeutic potentials of Tulsi from experience to facts, Drugs news and views.1(2):15-21.

Sheldon, J.W., M.J Balick and S Liard. (1997). Medicinal plants: can utilization and conservation co-exist? Scientific Publication, The New York Botanical Garden, USA. 